
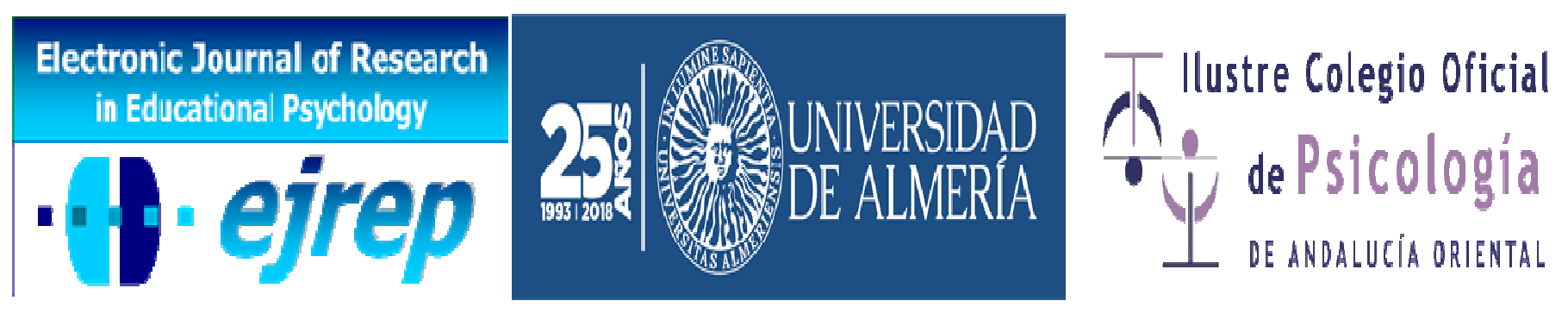

\title{
Sources of self-efficacy of English language learners with individual differences
}

\author{
Nattaporn Luangpipat
}

Faculty of Humanities, Naresuan University, Phisanulok

Thailand

Correspondence: Nattaporn Luangpipat. 99 Moo.9 Tambon Thapho Amphor Muang, Phitsanulok 65000. Thailand. E-mail: pornatta@yahoo.com

(C) University of Almería and Ilustre Colegio Oficial de la Psicología de Andalucía Orirental (Spain) 


\begin{abstract}
Introduction. Since self-efficacy is a belief about one's capability in doing something successfully or unsuccessfully and it relates to academic achievements directly and indirectly. The understanding the sources of one's self-efficacy could assist that person to achieve a better result in learning or doing something, or, at least, to minimize a reflection from negative sources that could decrease his/her self-efficacy. This study investigated the sources of selfefficacy of English language learners with different genders, nationalities, types of study program, and fields of study.
\end{abstract}

Method. This study used stratified random sampling to draw 480 first-year students at a university to complete a questionnaire. Then, the data was analyzed by descriptive statistics, ttest, and One-Way ANOVA.

Results. The result showed slight differences in sources of self-efficacy between learners with different nationality and types of program. Findings revealed that vicarious experience became the highest ranked source for positive self-efficacy while mastery experience was the highest for the negative self-efficacy. Social persuasion was the least influential source regardless of their differences.

Discussion and Conclusion. The implications are that teachers and administrators could use the results of this study to develop the strategies to implant positive self-efficacy that results greatly in students' learning process, and to lead their students with those individual differences to be autonomous learners.

Keywords: Self-efficacy, English language, English learner, individual difference 


\section{Resumen}

Introducción. La autoeficacia es una creencia sobre la capacidad de uno de hacer algo con éxito o sin éxito, y se relaciona con los logros académicos directa e indirectamente. La comprensión de las fuentes de la autoeficacia de cada uno podría ayudar a esa persona a lograr un mejor resultado en aprender o hacer algo, o, al menos, minimizar un reflejo de fuentes negativas que podrían disminuir su autoeficacia. Este estudio investigó las fuentes de autoeficacia de los estudiantes del idioma inglés con diferentes géneros, nacionalidades, tipos de programas de estudio y campos de estudio.

Método. Este estudio usó muestreo aleatorio estratificado para atraer a 480 estudiantes de primer año en una universidad para completar un cuestionario. Luego, los datos se analizaron mediante estadísticas descriptivas, prueba t y ANOVA de una vía.

Resultados. El resultado mostró ligeras diferencias en las fuentes de autoeficacia entre los estudiantes con diferentes nacionalidades y tipos de programas. Los resultados revelaron que la experiencia vicaria se convirtió en la fuente mejor calificada para la autoeficacia positiva, mientras que la experiencia de dominio fue la más alta para la autoeficacia negativa. La persuasión social era la fuente menos influyente sin importar sus diferencias.

Discusión y conclusión. Las implicaciones son que los maestros y administradores podrían usar los resultados de este estudio para desarrollar estrategias para implantar una autoeficacia positiva que resulte en gran medida en el proceso de aprendizaje de los estudiantes, y para guiar a sus alumnos con esas diferencias individuales a ser aprendices autónomos.

Palabras clave: autoeficacia, idioma inglés, aprendiz de inglés, diferencias individuales. 


\section{Introduction}

Self-efficacy represents the idea of one's belief about his/her capability in succeeding or failing to do something (Bandura, 1984; Hsieh, 2004; Hsieh and Kang, 2010; Weaver, 2008). Self-efficacy has been associated with academic achievements in many studies (Gold, 2010; Abdullah, et al., 2006; Herron, Mills, and Pajares, 2007; Brown, Lent, \& Multon et al., 1991; Miller and Pajares, 1994; Pintrich and Schunk, 2010; Abedini and Rahimi, 2009; Schunk, 1991). These studies showed that self-efficacy promoted academic achievement directly and indirectly. For this reason, understanding the sources of one's self-efficacy could assist that person to achieve a better result in learning or doing something, or, at least, to minimize a reflection from negative sources that could decrease his/her self-efficacy. Besides, to push each student to be autonomous learners more, positive self-efficacy should be encouraged and should match with one's own personal characteristics. According to Bandura (1997) and Schunk (1991), there are four factors: (a) learners' past performance accomplishments or mastery experience, (b) modeling or vicarious experience, (c) verbal persuasion or social persuasion, and (d) physiological or emotional states that form one's self-efficacy.

Mastery experience refers to the interpreted result of past performance (Bandura 1994 and 1997). Learners who succeed in doing something, their self-efficacy increases; on the other hand, failure lowers their self-efficacy (Crozier, 1997). Bandura (1994) emphasized that students who perform well on English tests and earn high grades in English classes tend to develop a greater sense of confidence in their English capabilities. Conversely, low-test results and poor grades generally weaken students' confidence. Apart from mastery experience, the learners' observation of their peers' successfulness in performing tasks, or vicarious experience, also results in developing their self-efficacy levels (Bandura, 1997). According to Schunk (1991), people make comparisons with others in terms of age, gender, race, nationality, educational and socioeconomic level, or background, ethnic group, level of income, designation, etc. Moreover, learners who receive an influence from authoritative figures such as parents, teachers, and/or trusted peers that they are capable of learning or doing something tend to see themselves as capable ones too. This factor is verbal or social persuasion (Bandura, 1997). The last factor is physiological or emotional states during activities, which they interpret as competence or incompetence. For example, bodily symptoms signaling anxiety might indicate a lack of skills or low self-efficacy (Schunk, 1989). In short, sources of selfefficacy in this study is based on sources of Bandura (1986)'s self-efficacy. The factors cover 
mastery experience (ME), vicarious experience (VE), social persuasion (SP), and emotional states (ES).

Although many studies (Arslan, 2012; Britner and Parajes, 2006; Chin and Kameoka, 2002; Gainor and Lent, 1998; Kiran and Sungur, 2012; Klassen, 2004; Lent and Lopez, 1992; Luzzo, et al., 1999; Matsui, et al., 1990; Johnson, Pajares, and Usher, 2006, 2007; Usher, 2009; Wang, 2004) have tried to examine sources contributing to students' self-efficacy, the findings are not consistent. Bandura (1986), Johnson, et al. (2007), Kiran and Sungur, (2012), and Luzzo, et al. (1999), believed that mastery experience was the most powerful source, while Bentz (2010), Hamman, Olivarez, \& Steven (2006), Hampton (1998), Klassen (2004), Luangpipat \& Padgate (2015), Matsui et al. (1990), and Pajares and Usher (2006) showed that vicarious experience became the highest factor related to the students' self-efficacy. Social persuasion became a vital source of self-efficacy in the work of Chin and Kameoka (2002), Gainor and Lent (1998), and Wang (2004). With these diverse outcomes, the verification of the result requires more studies.

Regarding individual differences in second/foreign language acquisition, gender is one of the most influential factor on language learners (Ahat, 2013, Andreou, Andreou and Vlachos, 2005, Saidi, 2012). Although there are many studies on gender, it is rarely to find a study focusing on sources of self-efficacy between different genders (Mesri, 2012). In addition to gender, the learners with different personal values adhering to different cultures may report different sources of self-efficacy (Dinthera, Dochyb, and Segersc, 2011). Nationality, race, or ethnicity has effects on students as they formulate students' characteristics with social norms, beliefs, values, and cultural practices (Lau, Liem, and Nie, 2008; Saidi, 2012), yet, the sources of self-efficacy for different nationalities have been infrequently mentioned (Pajares and Usher, 2006). However, gender and nationality are not the only differences found in learning. Since type of program could serve the expansion of international programs, understanding those differences contributed to sources of one's self-efficacy may support both teachers and students in handling the classrooms and developing the learning process (Geitz, Brinke, and Kirschner, 2016). Besides, students from different field of study under the higher education context carry particular characteristic (Gál, Holienka, and Holienková, 2015). Thus, this study also convers type of study program representing using mother tongue or English as a medium of instruction and field of study comprising three main categories: Science and Technology, Health Science, and Social Science. 
Overall, individual differences in this study cover gender, nationality: Thai and foreign students, students studying in different types of program: Thai and International program and field of study, which are science and technology, health science, and social science. Age is included in this study as the age of the population, the first year students aged 17-18, is too narrow to find any difference saliently.

\section{Objectives and hypothesis}

In order to understand what lies under the self-efficacy of English language learners with individual differences, this study aims to; firstly, observe perceived self-efficacy of the English language learners at Naresuan University. After that, the study compares sources selfefficacy of those English learners with the aim to answer the following questions:

RQ1: Is there any difference between perceived self-efficacy of students with different gender, nationality, type of program, and field of study?

RQ2: Is there any difference between sources of self-efficacy of students with different gender, nationality, type of program, and field of study?

The result of this study could be widely beneficial for students, teachers, parents, and academic staff. Firstly, after they know what could affect their learning's motivation and achievement, the learners might be more careful in accepting negative inputs and promote positive inputs. For teachers and parents, this research could guide them which direction they should support their students or their children. The teacher is also able to prepare the class activities and materials that are more suitable for the students in multi-cultural classroom or in co-educational institutions.

\section{Method}

\section{Participants}

The population of the study comprised all first-year students who enrolled in Fundamental English course (00112) in the academic year 2016. Fundamental English is one of compulsory subjects for the first year students at Naresuan University. Naresuan University was a location of data collection for this study because it is the largest public university in the lower-northern part of Thailand with approximately 20,000 full time students with various characteristics and studying in various programs. The first-year students are selected to be the 
population and sample of this study to minimize the possibility of students' self-efficacy from English language courses in the higher year of their study. The estimated number of population is 4,700 based on the university's statistics. With the large number of students, the study could not cover all students. The number of the sample was calculated by Taro Yamane (1976)'s formula. The sample group is 480 students: 370 from Thai programs and 110 from international programs. After getting the number, the sample was random by the ratio of group of the students. The students who study Thai programs are from 16 faculties grouped into three clusters: Health Sciences, Science and Technology, and Social Sciences (Division of Research Administration, 2012). The Health Sciences included the faculties of Nursing, the Allied Health Sciences, Pharmaceutical Sciences, Medical Sciences, Medicine, Dentistry, and Public Health. The Science and Technology included the faculties of Architecture, Science, Engineering, Agriculture, and Natural Resources and Environment. The Social Sciences included the faculties of Humanities, Social Sciences, Management and Information Science, Education, Law. The data were collected from random section corresponded to the number of samples as shown in Table 1.

Table 1. Number of sample according to stratified random sampling

\begin{tabular}{|c|c|c|c|}
\hline Number of population & & $N$ & $\%$ \\
\hline Thai programs $(\mathrm{N}=4575)$ & & $(n=367) 370$ & 100.00 \\
\hline Health science & & 90 & 24.15 \\
\hline Science and technology & & 130 & 35.19 \\
\hline Social science & & 150 & 40.66 \\
\hline \multirow[t]{2}{*}{ International programs $(\mathrm{N}=146)$} & & $(\mathrm{n}=107) 110$ & 100.00 \\
\hline & Total & 480 & 200.00 \\
\hline
\end{tabular}

\section{Instruments}

This study used questionnaire to elicit the students' levels of self-efficacy and sources. The questionnaire was adapted from Luangpipat \& Padgate (2015)'s study. The questionnaire had Cronbach's Alpha reliable coefficient $(\alpha)$ at .89 . The questionnaire divides into three parts: the students' general information, their perceived self-efficacy in English language learning, and sources of their self-efficacy. The students' general information includes gender, age, nationality, and faculty. The second part of the questionnaire is the students' perceived self-efficacy comprising 4 levels of perceived self-efficacy from highly confident and confident (No.1 and No.2), and not so confident and not confident at all (No.3 and No.4). The third part of the questionnaire is the sources of self-efficacy containing two parts: 3A and 3B. Each 
part comprises 16 items. Questions 1 to 4 represent mastery (ME), question 5 to 8 represent vicarious experience (VE), question 9 to 12 represent social persuasion (SP), and question 13 to 16 represent emotional states (ES). The participants who choose No.1 or No.2 in the second part do 3A, and the ones who chose No.3 and No.4 do 3B.

\section{Procedure}

The researcher distributed the questionnaire either before or after the lesson depending on the instructors' and the students' permission and convenience. The data was collected in the beginning of the first semester before the mid-term examination to minimize the influence of emotional states on the participants that might occur during the examination period. It normally took the students 10-15 minutes to complete the questionnaire. After that, the data from the questionnaires was analyzed.

\section{Data Analysis}

This study used SPSS version 17.0 for Windows (IBM® SPSS® Statistics 17.0) to analyze the data. T-test was used to compare the level of self-efficacy and sources of selfefficacy for students who have different gender, nationality, and type of program. The results was presented in descriptive statistics: mean and standard deviation. This study also used One-Way ANOVA to analyze the level of self-efficacy and sources of self-efficacy for students from different fields of study. The result was presented in one-way analysis of variance and multiple comparisons of students from different fields of study.

Level of self-efficacy is a belief of a student's capability to learn the English language, including the belief that he or she can reach a certain level of English language mastery (Bandura, 1994). In this study, the level of perceived self-efficacy was firstly divided into 1 to 4 1evels, 0.00-1.00 represents 'no confidence at all', 1.01-2.00 means 'not so confident', 2.013.00 is 'rather confident', and 3.01-4.00 stands for 'very confident'. Then, the perceived selfefficacy was grouped roughly as high or positive self-efficacy (more than 2.00) and low or negative self-efficacy (less than 2.00) to categorize sources of self-efficacy into positive and negative sources. 
Rank of sources of self-efficacy is represent by number one to four. One is the highest contributor to the learners' perceived self-efficacy and four is the lowest contributor to the learners' perceived self-efficacy.

\section{Results}

RQ1: Is there any difference between perceived self-efficacy of students with different gender, nationality, type of program, and field of study?

H1: There is a difference between perceived self-efficacy of students with different genders, nationalities, types of program, and fields of study.

$\mathrm{H} 2$ : There is no difference between perceived self-efficacy of students with different genders, nationalities, types of program, and fields of study.

Table 2. Mean and S.D. of self-efficacy level of students with different gender, nationality, and type of program (Total $n=480$ )

\begin{tabular}{lcccccc}
\hline \multicolumn{1}{c}{ Variables } & $n$ & Mean $(\mathrm{X})$ & S.D. & Meaning & $t$ & $p$ \\
\hline Gender & 134 & 2.39 & .76 & Rather confident & -.05 & .96 \\
Male & 346 & 2.38 & .73 & Rather confident & & \\
Female & & & & & & \\
Nationality & 476 & 2.38 & .73 & Rather confident & -.3 .05 & $.00^{*}$ \\
Thai & 4 & 3.50 & 1.00 & Very confident & & \\
Foreigner & & & & & & \\
Type of program & 370 & 2.34 & .74 & Rather confident & -2.75 & $.00^{*}$ \\
Thai program & 110 & 2.55 & .74 & Rather confident & & \\
International program & & & & & &
\end{tabular}

Table 2 summarized the result from t-test. It provides the evidence that there are significant differences of self-efficacy level between different Thai and foreign students and students who study in Thai and international program while there is no significant difference of self-efficacy level between male and female students.

Different nationality reveals a statistically significant difference with the significant level at 0.01. It shows that foreign students have higher level of perceived self-efficacy, that is, foreign students are more confident in learning English than Thai do. 
In terms of type of program, the result shows the statistically significant difference between the students who study in Thai program and those who study in international program. The ones who are in international program have slightly higher perceived self-efficacy, or confidence.

The differences found in both nationality and type of program are mainly from the foreign students who leave their home to study abroad and the students who study in international program. Both groups of the students have opportunity to expose to English language and use it more in their daily life than the students who are Thai or study in Thai program. According to Ellis and Tanaka (2003), one of the benefits of study abroad is that it strengthens the students' beliefs about language learning. The more often they use it, the more they get familiar with it and that results in the growth of their confidence.

Table 3. Mean and SD of perceived self-efficacy level of students with different field of study

\begin{tabular}{lcccc}
\hline \multicolumn{1}{c}{ Field of Study } & $n$ & Mean $(\mathrm{X})$ & S.D. & Meaning \\
\hline Health science & 90 & 2.62 & .712 & Rather confident \\
Science and technology & 130 & 2.11 & .638 & Rather confident \\
Social science & 150 & 2.36 & .771 & Rather confident \\
& 370 & 2.36 & .707 & Rather confident \\
\hline
\end{tabular}

Table 4. One-way analysis of variance of self-efficacy level of students with different field of

\begin{tabular}{|c|c|c|c|c|c|}
\hline Field of Study & $d f$ & $S S$ & $M S$ & $F$ & Sig. \\
\hline Between Groups & 2 & 12.24 & 7.12 & 14.03 & $.00 *$ \\
\hline Within Groups & 367 & 186.21 & .51 & & \\
\hline Total & 369 & 200.44 & & & \\
\hline
\end{tabular}

Table 5. Multiple Comparisons of Self-Efficacy Level of Students with Different Field of Study

\begin{tabular}{|c|c|c|c|c|c|c|}
\hline \multirow{2}{*}{\multicolumn{2}{|c|}{ 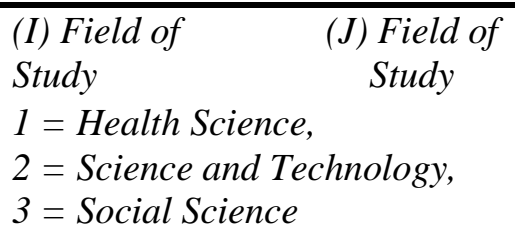 }} & \multirow{2}{*}{$\begin{array}{c}\text { Mean Differ- } \\
\text { ence } \\
(I-J)\end{array}$} & \multirow[t]{2}{*}{$\begin{array}{l}\text { Std. } \\
\text { Error }\end{array}$} & \multirow[t]{2}{*}{ Sig. } & \multicolumn{2}{|c|}{$\begin{array}{c}95 \% \text { Confidence } \\
\text { Interval }\end{array}$} \\
\hline & & & & & $\begin{array}{l}\text { Lower } \\
\text { Bound }\end{array}$ & $\begin{array}{l}\text { Upper } \\
\text { Bound }\end{array}$ \\
\hline \multirow[t]{2}{*}{1} & 2 & $.52 *$ & .09 & $.00 * *$ & .29 & .74 \\
\hline & 3 & $.26 *$ & .10 & $.02 *$ & .03 & .49 \\
\hline \multirow[t]{2}{*}{2} & 1 & $-.52 *$ & .09 & .00 & -.74 & -.29 \\
\hline & 3 & $-.25^{*}$ & .08 & $.01 * *$ & -.45 & -.05 \\
\hline \multirow[t]{2}{*}{3} & 1 & $-.26 *$ & .10 & .02 & -.49 & -.03 \\
\hline & 2 & $.25^{*}$ & .08 & .01 & .05 & .45 \\
\hline
\end{tabular}


Table 3, 4, and 5 show the results from One-Way ANOVA. Table 3 displays the mean and meaning of the students' perceived self-efficacy. Students who study in Health science have highest self-efficacy, followed by students in Social science, and Science and Technology. Table 4 reveals statistically significant differences in the self-efficacy level between students who study in different fields. The comparison between specific groups in Table 5 shows that the level of self-efficacy of students in Health science differs from students in science and technology the most with the significant level at .00 . It is followed by the difference between level of self-efficacy of the students in Social Science and Students in Science and Technology, and students in Health Science and Social Science with the significant level at .01, and .02 respectively.

This result reflects the society praise the students who study in health science group comprising students from the Faculty of Medicine, Pharmacy, Nursing, etc. as good students. In Asia cultures, especially Thai society, the top students from high schools generally aim and reserve the seats to study in those fields. They carry with them the pride and the high level of self-confidence, particularly in learning. There is no surprise that their self-efficacy level is higher than other groups. Science and Technology are the students from Faculty of Engineering, Agriculture, Architecture, etc., those types of students who prefer Math, Physics, Chemistry, and Biology than languages. They always believed languages, specifically English language, are their enemy. That is why their self-efficacy as English learners becomes the lowest.

In summary, with those individual differences, there is no difference in the level of self-efficacy between different gender for English learners in Thailand, but the difference of English learners' level of self-efficacy shows in different nationality, type of program, and field of study.

RQ2: Is there any difference between sources of self-efficacy of students with different gender, nationality, type of program, and field of study?

H1: There is a difference between sources of self-efficacy of students with different gender, nationality, type of program, and field of study.

$\mathrm{H} 2$ : There is no difference between sources of self-efficacy of students with different gender, nationality, type of program, and field of study. 
Table 6. Sources of perceived self-efficacy of students with different gender

\begin{tabular}{llccccc}
\hline \multicolumn{1}{c}{ Sources of self-efficacy } & Gender & $n$ & Mean (X) & S.D. & $t$ & $p$ \\
\hline High self-efficacy & & & & & & \\
Mastery experience & Male & 53 & 2.92 & .48 & 1.23 & .22 \\
& Female & 144 & 3.00 & .44 & & \\
Vicarious experience & Male & 53 & 3.22 & .46 & 1.74 & .08 \\
& Female & 144 & 3.35 & .46 & & \\
Social persuasion & Male & 53 & 2.62 & .57 & 1.40 & .16 \\
& Female & 144 & 2.75 & .58 & & \\
Emotional states & Male & 53 & 2.98 & .45 & .24 & .81 \\
Low self-efficacy & Female & 144 & 3.00 & .63 & & \\
Mastery experience & & & & & & \\
& Male & 81 & 2.57 & .59 & -1.03 & .31 \\
Vicarious experience & Female & 202 & 2.49 & .59 & & \\
& Male & 81 & 1.98 & .71 & .87 & .38 \\
Social persuasion & Female & 202 & 2.06 & .70 & & \\
& Male & 81 & 1.95 & .67 & -.68 & .50 \\
Emotional states & Female & 202 & 1.88 & .74 & & \\
& Male & 81 & 2.15 & .82 & .61 & .54 \\
\hline
\end{tabular}

Table 6 shows that there are no statistically significant differences of sources of selfefficacy between male and female students. However, ranking the sources from the mean, sources of self-efficacy for high self-efficacy of male and female is slightly different. Although both of them rated vicarious as the highest source for their self-efficacy and social persuasion the last, the second and third rank is opposite. Female chose mastery experience before emotional states while, surprisingly, male chose emotional states over mastery experience. The ranks of sources of self-efficacy for low self-efficacy of male and female are the same: mastery experience, emotional states, vicarious experience, and social persuasion.

Table 7. Sources of perceived self-efficacy of students with different nationality

\begin{tabular}{lcccccc}
\hline \multicolumn{1}{c}{ Sources of self-efficacy } & Nationality & $n$ & Mean (X) & S.D. & $t$ & $p$ \\
\hline High self-efficacy & & & & & & \\
Mastery experience & Thai & 194 & 2.97 & .45 & -2.16 & $0.03^{*}$ \\
& Foreigner & 3 & 3.53 & .12 & & \\
Vicarious experience & Thai & 194 & 3.31 & .47 & -1.83 & $0.07^{*}$ \\
& Foreigner & 3 & 3.80 & .20 & & \\
Social persuasion & Thai & 194 & 2.70 & .57 & -2.71 & $0.01^{* *}$ \\
& Foreigner & 3 & 3.60 & .40 & & \\
Emotional states & Thai & 194 & 2.99 & .58 & -2.01 & $0.05^{*}$ \\
& Foreigner & 3 & 3.67 & .42 & & \\
Low self-efficacy & & & & & & \\
Mastery experience & Thai & 282 & 2.51 & .59 & 1.21 & .23 \\
& Foreigner & 1 & 1.80 & - & & \\
Vicarious experience & Thai & 282 & 2.04 & .71 & 1.47 & .14 \\
\hline
\end{tabular}




\begin{tabular}{lcccccc}
\hline \multirow{3}{*}{ Social persuasion } & Foreigner & 1 & 1.00 & - & & \\
& Thai & 282 & 1.90 & .72 & 1.25 & .21 \\
& Foreigner & 1 & 1.00 & - & & \\
Emotional states & Thai & 282 & 2.19 & .81 & .24 & .81 \\
& Foreigner & 1 & 2.00 & - & & \\
\hline
\end{tabular}

$* p<0.05, * * p<0.01$

From Table 7, it demonstrated that there are significant differences of sources of selfefficacy between Thai and foreign students in high self-efficacy group. It showed those sources have more influences on foreign students than Thai students especially in implanting positive believes. In low self-efficacy group, there are no statistically significant differences of sources of self-efficacy between Thai and foreign students. However, due to the limited number of foreign students, it could not represent the result perfectly.

In terms of ranks of sources of high self-efficacy for Thai and foreign students, vicarious experience and emotional states becomes the highest sources for both groups. Mastery experience and social persuasion are the follow-up sources of self-efficacy for Thai students while foreign students ranked mastery experience the last source of their self-efficacy.

Table 8. Sources of perceived self-efficacy of students with different type of program

\begin{tabular}{lcccccc}
\hline Sources of Self-Efficacy & Type of Program & $n$ & Mean & S.D. & $t$ & $p$ \\
\hline High self-efficacy & & & & & & \\
Mastery experience & Thai & 139 & 2.93 & .44 & -2.42 & $.02 *$ \\
& International & 58 & 3.10 & .45 & & \\
Vicarious experience & Thai & 139 & 3.24 & .47 & -3.52 & $.00^{* *}$ \\
& International & 58 & 3.49 & .40 & & \\
Social persuasion & Thai & 139 & 2.63 & .56 & -3.14 & $.00^{* *}$ \\
& International & 58 & 2.91 & .58 & & \\
Emotional states & Thai & 139 & 2.94 & .57 & -2.34 & $.02 *$ \\
& International & 58 & 3.15 & .58 & & \\
Low self-efficacy & & & & & & \\
Mastery experience & Thai & 139 & 2.57 & .59 & 3.43 & $.02 *$ \\
& International & 58 & 2.26 & .55 & & \\
Vicarious experience & Thai & 139 & 2.09 & .68 & 2.63 & $.01 * *$ \\
& International & 58 & 1.80 & .78 & & \\
Social persuasion & Thai & 139 & 1.92 & .73 & 1.18 & .24 \\
& International & 58 & 1.79 & .71 & & \\
Emotional states & Thai & 139 & 2.22 & .81 & .972 & .33 \\
& International & 58 & 2.10 & .78 & & \\
\hline
\end{tabular}


Table 8 reveals that there are statistically significant differences between the sources of self-efficacy of students who study in Thai and International program. Social persuasion and emotional states are only two sources that have no different influence on students with low self-efficacy. The numbers demonstrated that students in international program rated every source of self-efficacy that promotes positive self-efficacy higher than the students in Thai program do. On the contrary, they rated every source negative self-efficacy than the Thai students did.

In terms of ranks of sources of high self-efficacy for students who study in Thai and international program, both groups have the same ranks which are vicarious experience, emotional states, mastery experience, and social persuasion for positive self-efficacy while the ranks of sources for negative self-efficacy are mastery experience, emotional states, vicarious experience, and social persuasion respectively.

Table 9. Sources of perceived self-efficacy of students with different field of study

\begin{tabular}{|c|c|c|c|c|c|c|}
\hline Sources of self-efficacy & Field of study & $n$ & Mean & S.D. & $F$ & Sig. \\
\hline \multicolumn{7}{|l|}{ High self-efficacy } \\
\hline \multirow[t]{4}{*}{ Mastery experience } & Health science & 52 & 3.02 & .44 & 1.84 & .162 \\
\hline & Science and technology & 28 & 2.86 & .30 & & \\
\hline & Social science & 59 & 2.89 & .48 & & \\
\hline & Total & 139 & 2.93 & .44 & & \\
\hline \multirow[t]{4}{*}{ Vicarious experience } & Health science & 52 & 3.34 & .43 & 2.052 & .132 \\
\hline & Science and technology & 28 & 3.15 & .39 & & \\
\hline & Social science & 59 & 3.19 & .53 & & \\
\hline & Total & 139 & 3.24 & .47 & & \\
\hline \multirow[t]{4}{*}{ Social persuasion } & Health science & 52 & 2.74 & .54 & 1.535 & .219 \\
\hline & Science and technology & 28 & 2.59 & .34 & & \\
\hline & Social science & 59 & 2.56 & .65 & & \\
\hline & Total & 139 & 2.63 & .56 & & \\
\hline \multirow[t]{4}{*}{ Emotional states } & Health science & 52 & 2.94 & .62 & .155 & .856 \\
\hline & Science and technology & 28 & 2.99 & .46 & & \\
\hline & Social science & 59 & 2.91 & .59 & & \\
\hline & Total & 139 & 2.94 & .57 & & \\
\hline \multicolumn{7}{|l|}{ Low self-efficacy } \\
\hline \multirow[t]{4}{*}{ Mastery experience } & Health science & 38 & 2.58 & .61 & .107 & .899 \\
\hline & Science and technology & 102 & 2.55 & .61 & & \\
\hline & Social science & 91 & 2.58 & .56 & & \\
\hline & Total & 231 & 2.57 & .59 & & \\
\hline \multirow[t]{4}{*}{ Vicarious experience } & Health science & 38 & 2.15 & .61 & .779 & .460 \\
\hline & Science and technology & 102 & 2.03 & .69 & & \\
\hline & Social science & 91 & 2.13 & .70 & & \\
\hline & Total & 231 & 2.09 & .68 & & \\
\hline \multirow[t]{3}{*}{ Social persuasion } & Health science & 38 & 1.93 & .75 & .003 & 997 \\
\hline & Science and technology & 102 & 1.92 & .77 & & \\
\hline & Social science & 91 & 1.92 & .67 & & \\
\hline
\end{tabular}




\begin{tabular}{|c|c|c|c|c|c|c|}
\hline \multirow{5}{*}{ Emotional states } & Total & 231 & 1.92 & .73 & \multirow{5}{*}{.351} & \multirow{4}{*}{.704} \\
\hline & Health science & 38 & 2.32 & .94 & & \\
\hline & Science and technology & 102 & 2.21 & .82 & & \\
\hline & Social science & 91 & 2.19 & .74 & & \\
\hline & Total & 231 & 2.22 & .81 & & \\
\hline
\end{tabular}

Table 9 shows that there are no statistically significant differences between sources of self-efficacy of the students who study in different fields. Different groups ranked the sources similarly. For positive self-efficacy, vicarious experience is the most influential source for their perceived self-efficacy, followed by emotional states, mastery experience, and social persuasion. Only students in health science rated mastery experience slightly higher than emotional states. Due to the nature of high competition in studying of this group of the students, grades and scores are what most of them put their efforts toward and pay high attention to. The success or failure means more to the students in health science group than the other two groups.

For low self-efficacy or negative self-efficacy, the ranks are all the same for all groups that are mastery experience, emotional states, vicarious experience, and social persuasion. The result reveals that failure could cause bigger and longer impact on the students' perception of themselves, as it becomes number one source for negative self-efficacy while it is the third in creating positive self-efficacy.

In conclusion, the first and the last sources of positive self-efficacy of English learners are the same that are vicarious experience as the first and social persuasion at the last. Students studying in different programs, fields of study, nationality and male students ranked emotional states in the second place and rated mastery experience as their third source. Female ranked mastery experience over emotional states. For students with low or negative selfefficacy, regardless of those individual differences, the sources are in the same order that are mastery experience, emotional states, vicarious experience, and social persuasion. 


\section{Discussion and Conclusions}

As level of perceived self-efficacy of English learners with different nationality, type of program, and field of study has been rarely studies, there is limited works to compare. However, for gender, some studies mentioned the different level of self-efficacy. For example, Tenaw (2013) states that there is significant difference in their self-efficacy between male and female. The result from various researches (Britner and Pajares, 2001; Mesri, 2012; Saidi, 2012; Webb-Williams, 2014) showed that male rated lower perceived self-efficacy than female. However, the result of this study showing no significant difference in the level of selfefficacy between male and female is similar to some previous studies (Hampton and Mason, 2003; Tercanlioglu 2005; Mesri, 2012; Mansor and Sawari, 2013). In terms of levels of selfefficacy of the students in different fields, the work of Huang (2013), only mentioned about the preference of males in mathematics, computer, and social sciences while females preferred arts and language. However, those studies have not grouped the students according to general characteristic of each field as this study did.

Regarding sources of positive self-efficacy in the overall picture, vicarious become the first sources that students with any differences rely on which is similar to many studies (Bentz (2010), Hamman, et al., 2006; Hampton, 1998; Hodges and Murphy, 2009; Jansen, Scherer, and Schroeders, 2015; Klassen, 2004; Luangpipat \& Padgate, 2015; Matsui et al., 1990; Pajares and Usher, 2006). However, the results contrast with the result of the mainstream of previous researches stating mastery experience as the most important source (Bandura, 1986; Johnson, et al., 2007; Kiran and Sungur, 2012; Luzzo, et al., 1999). It demonstrates the university students compare their abilities with their classmates and receive the influenced from the social comparison processes in the classroom. This reflects a collective nature of Asian students who rely mostly on group's opinion. Bandura (1997) emphasized that vicarious experience could be the most influential factor when students have limited experiences or are uncertain about their capabilities to accomplish a task. With the age of the students in this study, between 17-19 years old, it is possible to assume that they have limited experience and cannot have absolute judgment on their own capability. Consequently, their peers are likely to be the most influential persons. A possibility that vicarious experience became the highest factor related to the students' self-efficacy in this study due to the fact that the students considered their peers as a reliable source (Luangpipat \& Padgate, 2015). Since Newcomb (1962) 
mentioned that a group had power over their members, collecting data in the classroom which students sat in groups and shared some experiences might be a cause of this result.

Social persuasion is the last sources that students give importance to when they consider about their self-efficacy which is different from the work of Chin and Kameoka (2002), Gainor and Lent (1998), Locke and Phan (2015), and Wang (2004). Butz and Usher (2015) stated that students with high self-efficacy were more likely to describe social persuasion as a source than were those with low self-efficacy. However, the result from this study showed that either high or low self-efficacy students showed social persuasion as their least influential source of self-efficacy. The result from this study quite shakes the beliefs in Asian context that the students nowadays pay less attention to what teachers or parents say which is totally opposite to the older generation.

The second and third place for sources of self-efficacy of male and female is opposite. Female chose mastery experience before emotional states while male chose emotional states over mastery experience. This result is contrast with a few studies. For example, Erikson (1968) stated that males define their developing identity by their accomplishments while Pajares and Usher (2006) said that girls' satisfaction with relationships is more important than their previous accomplishments. According to Pajares and Usher (2006), mastery experience had more influence on boys' self-efficacy than did the other sources combined whereas social persuasion was the only influential sources of self-efficacy for girls. The reason for female students ranking mastery experience higher than emotional states could be that women students felt more embarrassed by their mistakes, the experience they received last longer impact on their minds (Coleman, 1996).

Educational designers and practitioners could utilize the results of this study. Firstly, English teachers, especially in co-education institutes or multi-cultural classes, must consider gender and nationality differences in order to select appropriate teaching strategies and methods (Saidi, 2012). Moreover, teachers should introduce the role of helpful vicarious learning such as assigning pair work or small group work in classrooms more since the result found vicarious experience as the most potential factor (Morris, 2004). Besides, according to Chan, Raoofi, and Tan (2012), students should have more opportunities to observe their friends or classmates do tasks successfully, which will help fostering them positive selfefficacy. 
For the second source, emotional states, Young (1990) recommended the use of humor in class in order to create friendly, supportive, and relaxing classroom atmosphere in order to reduce students' anxiety and tense, which is result in the students' emotion that affect positively or negatively results in their learning process. For mastery experience, setting the challenging task with reachable goals are what teachers should encourage the students (Margolis and McCabe, 2006). Although social persuasion was the lowest ranked source of students' self-efficacy, Bandura (1977) mentioned feedback could support the process transforming low self-efficacy into high. Therefore, teachers and parents should carefully the messages they send to the students since those messages could later become the messages students send to themselves (Pajares and Usher, 2006).

In order to handle the cross-cultural environment classroom more effective and bring learning that is more autonomous to each student, teachers need to take those individual differences and the sources of self-efficacy of each individual into the consideration. Teachers can mix and match the sources of self-efficacy with the differences to tailor the materials, activities, and supporting environment for the individuals in language classroom.

\section{References}

Abdullah, M.C, Cheong, L.S., Elias, H., Mahyuddin, R., Muhamad, M.F., \& Noordin, N. (2006). The Relationship between students' self-efficacy and their English language achievement. Journal Pendidik dan Pendidikan, 21, 61-71. Retrieved September 18, 2016, from http://citeseerx.ist.psu.edu/viewdoc/download?doi=10.1.1.485.2420\&rep=re p1\&type $=$ pdf.

Abedini, A. Rahimi, A. (2009). The interface between EFL learners' self-efficacy concerning listening comprehension and listening proficiency. Retrieved October 15 2016, from www.novitasroyal.org/ archives/vol-3-issue-1.

Ahat, R. (2013). Motivation, gender, and learner performance of English as an 13 in the Xinjiang Uyghur autonomous region. English Language Teaching, 6(9), 158-167. DOI:10.5539/elt.v6n9p158. 
Andreou, E., Andreou, G., \& Vlachos, F., (2005). Affecting factors in second language learning. Journal of Psycholinguistic Research, 34(5), DOI: 10.1007/s10936-005-6202-0.

Arslan, A. (2012). Predictive power of the sources of primary school students' self-efficacy beliefs on their self-efficacy beliefs for learning and performance. Educational Sciences: Theory \& Practice, 12(3), 1915-1920. Retrieved January 20, 2017, from http://www.academia.edu/2329002/Predictive_Power_of_the_Sources_of_Primary_Sch ool_Students_Self-Efficacy_Beliefs_on_Their_SelfEfficacy_Beliefs_for_Learning_and _Performance.

Bandura, A. (1984). Recycling misconceptions of perceived self-efficacy. Cognitive Therapy and Research, 8, 231-255. DOI: 10.1007/BF01172995.

Bandura, A. (1986). The explanatory and predictive scope of self-efficacy theory. Journal of Clinical and Social Psychology, 4, 359-373. DOI: 10.1521/jscp.1986.4.3.359.

Bandura, A. (1994). Self-efficacy. In V. S. Ramachaudran (Ed.), Encyclopedia of Human Behavior, 4, 71-81. New York: Academic Press. Retrieved December 15, 2016 from https://www.uky.edu/ eushe2/Bandura/Bandura1994EHB.pdf.

Bandura, A. (1997). Self-efficacy: the exercise of control. Retrieved December 15, 2016, from http://www.uky.edu/ eushe2/Pajares/effbook11.html.

Bentz, M.R. (2010). Is segregation warranted?: Investigating the sources of self-efficacy for verbal English acquisition of English language learners. Arizona State University, ProQuest Dissertations Publishing. Retrieved October 5, 2016, from http://search.proqu est.com.ezproxy.library. wisc.edu/docview/305183310? accountid=465.

Britner, S. L. \& Pajares, F. (2006). Sources of science self-efficacy beliefs of middle school students. Journal of Research in Science Teaching, 43(5), 485-499. DOI: 10.1002/tea. 20131

Brown, S. D., Lent, R. W., \& Multon, K. D. (1991). Relation of self-efficacy beliefs to academic outcomes: A meta-analytical investigation. Journal of Counseling Psychology, 38, 30-38. DOI: 10.1037/0022-0167.38.1.30.

Butz, A. R., \& Usher, E.L. (2015). Salient sources of early adolescents' self-efficacy in two domains. Contemporary Educational Psychology. 42, pp. 49-61. https://doi.org/10.1016 /j.cedpsych.2015.04.001.

Chan, S.H., Raoofi, S., \& Tan, B.H., (2012). Self-efficacy in second/foreign language learning contexts. English Language Teaching, 5(11), 60-73. DOI: 10.5539/elt.v5n11p60. 
Chin, D. \& Kameoka, V. A. (2002). Psychosocial and contextual predictors of educational and occupational self-efficacy among Hispanic inner-city adolescents. Hispanic Journal of Behavioral Sciences, 24, 448-464. DOI: 10.1177/0739986302238214.

Cook, V. (2001). Second Language Learning and Language Teaching. London: Hodder Education, 114-139.

Crozier, W.R., (1997). Individual learners: Personality differences in education. New York: Routledge.

Dinthera, M.V., Dochyb, F., \& Segersc, M. (2011). Factors affecting students' self-efficacy in higher education. Educational Research Review 6(2), 95-108. https://doi.org/10.1016/ j.edurev.2010.10.003.

Division of Research Administration. (2012). Research at Naresuan. Retrieved October 1, 2016, from http://www.english.nu.ac.th/research/.

Ellis, R. \& Tanaka, K. (2003). Study-abroad, language proficiency, and learner beliefs about language learning. JALT journal, 25(1), 63-85. Retrieved September 20, 2017, from http://jalt-publications.org/archive/jj/2003a/art3.pdf.

Gainor, K. A. \& Lent, R. W. (1998). Social cognitive expectations and racial identity attitudes in predicting the math choice intentions of black college students. Journal of Counseling Psychology, 45, 403-413. DOI: 10.1037/0022-0167.45.4.403.

Gál, P., Holienka, M., \& Holienková, J. (2015). Entrepreneurial characteristics of students in different fields of study: a view from entrepreneurship education perspective. Acta Universitatis Agriculturae Et Silviculturae Mendelianae Brunensis, 63 (6), 2015. http://dx. doi.org/10.11118/actaun201563061879.

Geitz, G. Brinke, D.J. Paul A., \& Kirschner, P.A. (2016). Changing learning behavior: Selfefficacy and goal orientation in PBL groups in higher education. International Journal of Educational Research, 75, 146-158. https://doi.org/10.1016/j.ijer.2015.11.001.

Gold, J. G. (2010). The Relationship between self-Efficacy and achievement in at-risk high school students. Doctoral Dissertation, Ed.D. Walden University, Minnesota. Retrieved September 14, 2016, from https://search.proquest.com/docview/753941090.

Hamman, D., Olivarez, A., \& Stevens, T. (2006). The role of cognition, motivation, and emotion is explaining the mathematics achievement gap between Hispanic and white students. Hispanic Journal of behavior Sciences, 28, 161-186. DOI: 10.1177/07399863052 86103. 
Hampton, N.Z. \& Mason, E. (2003). Learning disabilities, gender, sources of efficacy, selfefficacy beliefs, and academic achievement in high school students. Journal of School Psychology, 41(2), 101-112. https://doi.org/10.1016/S0022-4405(03)00028-1.

Herron, C., Mills, N., \& Pajares, F. (2007). Self-efficacy of college intermediate French students: Relation to motivation, achievement, and proficiency. Language Learning, 57(3), 417-442. DOI: 10.1111/j.1467-9922.2007.00421.x.

Hsieh, P.H. (2004). How college students explain their grades in a foreign language course: The interrelationship of attributions, self-efficacy, language learning beliefs, and achievement. Retrieved May 21, 2013, from https://repositories.lib.utexas.edu/handle/ $2152 / 1332$.

Hsieh, P.H. \& Kang, H.S. (2010). Attribution and self-efficacy and their interrelationship in the Korean EFL context. Language Learning, 60(3), 606-627. DOI: 10.1111/j.1467-99 22.2010.00570.x.

Huang, C. (2013). Gender differences in academic self-efficacy: a meta-analysis. Eur J Psychol Educ. 28, 1-35. DOI: 10.1007/s10212-011-0097-y.

Johnson, M. J., Pajares, F., \& Usher, E. L. (2007). Sources of writing self-efficacy beliefs of elementary, middle and high school students. Research in the Teaching of English, 42, 104-120. Retrieved September 20, 2016, from https://sites.education.uky.edu/motiva tion/files/2013/08/PajaresJohnsonUsherRTE2007.pdf.

Kiran, D. \& Sungur, S. (2012). Source and consequences of Turkish middle school students' science self-efficacy. The Asia-Pacific Education Researcher, 21 (1), 172-180. Retrieved October 30, 2016, from https://webcache.googleusercontent.com/search?q=cach e:5RoyttEK2kcJ:https://ejournals.ph/article.php\%3Fid\%3D4325+\&cd=1\&hl=en\&ct=cl $\mathrm{nk} \& \mathrm{gl}=\mathrm{us}$.

Klassen, R. M. (2004). A cross-cultural investigation of the efficacy beliefs of South Asian immigrant and Anglo Canadian nonimmigrant early adolescents. Journal of Educational Psychology, 96, 731-742. http://dx.doi.org/10.1037/0022-0663.96.4.731.

Langworthy, A. (2007). Why universities are important to communities - the human capital perspective. Retrieved October 12, 2016 from http://www.utas.edu.au/_data/assets/pdf _file/0008/16001/Why-Study-at-University.pdf.

Lau, S., Liem, A.D., \& Nie, Y. (2008). The role of self- efficacy, task value, and achievement goals in predicting learning strategies, task disengagement, peer relationship, and achievement outcome. Contemporary Educational Psychology, 33(4), 486-512. https://doi.org/ 10.1016/j.cedpsych.2007.08.001. 
Lent, R.W. \& Lopez, F.G. (1992). Sources of mathematics self-efficacy in high school students. The Career Development Quarterly, 41, 3-12. DOI:10.1002/j.21610045.1992.tb 00350.x.

Locke, T. \& Phan, N.T. T. (2015). Sources of self-efficacy of Vietnamese EFL teachers: A qualitative study. Teaching and Teacher Education, 73-82. https://doi.org/10.1016/ j.tate.2015.09.006.

Luangpipat, N. \& Padgate, W. (2015). The relationship between English learning achievement and perceived self-efficacy of the first-year students at Naresuan University. Journal of Foreign Language Teaching and Applied Linguistics. 2(2). DOI: 10.14706/JFLT AL152218.

Luzzo, D. A., Hasper, P., Albert, K. A., Bibby, M. A. \& Martinelli, E. A. (1999). Effects of self-efficacy-enhancing interventions on the math/science career interests, goals, and actions of career undecided college students. Journal of Counseling Psychology, 46, 233 243. Retrieved October 30, 2016, from http://psycnet.apa.org/doiLanding?doi=10. 1037\%2F0022-0167.46.2.233.

Mansor, N. B. \& Sawari, S.S. (2013). A study of student's general self-efficacy related to gender differences. International Journal of Informative and Futuristic Research (IJIFR). 1(4), 62-67. Retrieved October 16, 2016, from https://www.researchgate.net/ publication/268210257_A_study_of_student's_general_self-efficacy_related_to_gen _differences.

Margolis, H. \& McCabe, P. (2006). Improving self-efficacy and motivation: What to do, what to say. Intervention in School and Clinic, 41(4), 218-227. Retrieved October 30, 2016, from http://journals.sagepub.com/doi/pdf/10.1177/10534512060410040401.

Matsui, K., Matsui, T. \& Ohnishi, R. (1990). Mechanisms underlying math self-efficacy learning of college students. Journal of Vocational Behavior, 37, 223-238. https://doi.org/10.1016/0001-8791(90)90042-Z.

Mesri, F. (2012). Exploring the gender effect on Iranian university learners' beliefs to learn English. International Journal of Academic Research in Business and Social Sciences. 2(6). 98-106. Retrieved October 15, 2016, from http://www.hrmars.com/admin/pics/822 .pdf.

Miller, M. D. \& Pajares, F. (1994). The role of self-efficacy and self-concept beliefs in mathematical problem solving: A path analysis. Journal of Educational Psychology, 86(2), 193-203. http://dx.doi.org/10.1037/0022-0663.86.2.193. 
Morris, L.V. (2004) Self-efficacy in academe: Connecting the belief and the reality. Innovative Higher Education, 28(3), 159-162. DOI: 10.1023/B:IHIE.0000015161.26089.a5.

Newcomb, T.M. (1962). Student peer-group influence. In Sanford, Nevitt (Ed.), the American college: A psychological and social interpretation of the higher learning, 469-488. US: John Wiley and Sons.

Norris - Holt, J. (2001). Motivation as a contributing factor in second language acquisition. The Internet TESL Journal, 7(6). Retrieved October 12, 2016, from http://iteslj.org/Arti cles/Norris-Motivation.html.

Pajares, F. (2002). Overview of social cognitive theory and of self-efficacy. Retrieved October 12, 2016, from http://www.emory.edu/EDUCATION/mfp/eff.html.

Pajares, F. \& Usher, E. L. (2006). Sources of Academic and Self-Regulatory Efficacy Beliefs of Entering Middle School Students. Contemporary Educational Psychology. 31 (2006) 125-141. https://doi.org/10.1016/j.cedpsych.2005.03.002.

Pintrich, P. R. \& Schunk, D. H. (2010). Motivation in education: theory, research and applications. Upper Saddle River, N.J.: Pearson/Merrill Prentice Hall.

Saidi, A.A. (2012). The influence of gender on Omani college students' English language learning strategies, comprehension and motivation. International Journal of Applied Linguistics \& English Literature, 1 (4), 230-244. DOI:10.7575/ijalel.v.1n.4p.230.

Schunk, D.H. (1989). Self-efficacy and achievement behaviors. Educational Psychology Review, 1, 173-208. https://doi.org/10.1007/BF01320134.

Schunk, D. H. (1991). Self-efficacy and academic motivation. Educational Psychologist, 26, 207-231. http://dx.doi.org/10.1207/s15326985ep2603\&4_2.

Tenaw. Y. A. (2013). Relationship between self-efficacy, academic achievement and gender in analytical chemistry at Debre Markos College of teacher education. Ajce, 3(1), 3-28. Retrieved October 15, 2016, from https://www.ajol.info/index.php/ajce/article/view/ $84850 / 74836$.

Tercanlioglu, L. (2005). Pre-service EFL teachers' beliefs about foreign language learning and how they relate to gender. Electronic Journal of Research in Educational Psychology, 5-3(1), 145-162. https://doi.org/10.1080/02619768.2011.643399.

Usher, E.L. (2009). Sources of middle school students' self-efficacy in Mathematics: a qualitative investigation. American Educational Research Journal.46(1), 275-314. DOI: 10.3102/0002831208324517.

Vas, L.S.R. (2008). Holistic living: build self-efficacy. Retrieved December 15, 2016, from https://www.lifepositive.com/build-self-efficacy/. 
Wang, C. (2004). Self- regulated learning strategies and self-efficacy beliefs of children learning English as a second language. Retrieved October 15, 2016, from https://etd.ohiolink.edu/rws_etd/document/get/osu1091546670/inline.

Weaver, J. (2008). Effect on self-efficacy on motivation and achievement among fifth grade science students. Retrieved October 16, 2016, from http://www.sciencedireect .com/science/article/pii/S1877042811027467.

Webb-Williams, J. (2014). Gender differences in schoolchildren's self-efficacy beliefs: students and teachers' perspectives. Educational Research and Reviews. 9(3), 75-82. DOI: 10.5897/ERR2013.1653.

Young, D.J. (1990). An investigation of students' perspectives on anxiety and speaking. Foreign Language Annals, 23, 539-553. DOI: 10.1111/j.1944-9720.1990.tb00424.x. 